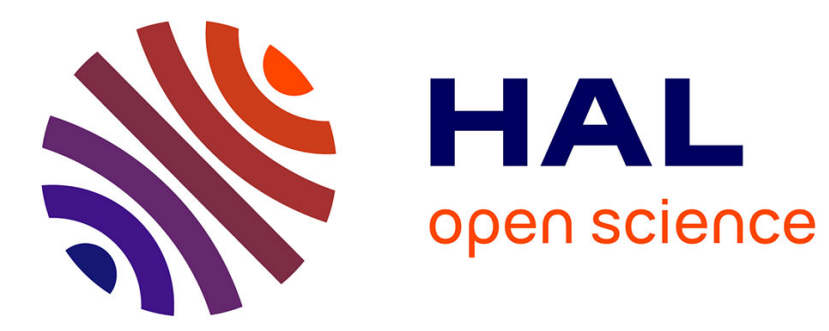

\title{
Functional fragmentation and the location of multinational firms in the enlarged Europe
}

\author{
Fabrice Defever
}

\section{To cite this version:}

Fabrice Defever. Functional fragmentation and the location of multinational firms in the enlarged

Europe. 2006. halshs-00118808

\section{HAL Id: halshs-00118808 \\ https://shs.hal.science/halshs-00118808}

Submitted on 6 Dec 2006

HAL is a multi-disciplinary open access archive for the deposit and dissemination of scientific research documents, whether they are published or not. The documents may come from teaching and research institutions in France or abroad, or from public or private research centers.
L'archive ouverte pluridisciplinaire HAL, est destinée au dépôt et à la diffusion de documents scientifiques de niveau recherche, publiés ou non, émanant des établissements d'enseignement et de recherche français ou étrangers, des laboratoires publics ou privés. 


\title{
Centre d'Economie de la Sorbonne
} UMR 8174

\author{
Functional Fragmentation and the Location of \\ Multinational Firms in the Enlarged Europe
}

Fabrice DEFEVER

2006.52
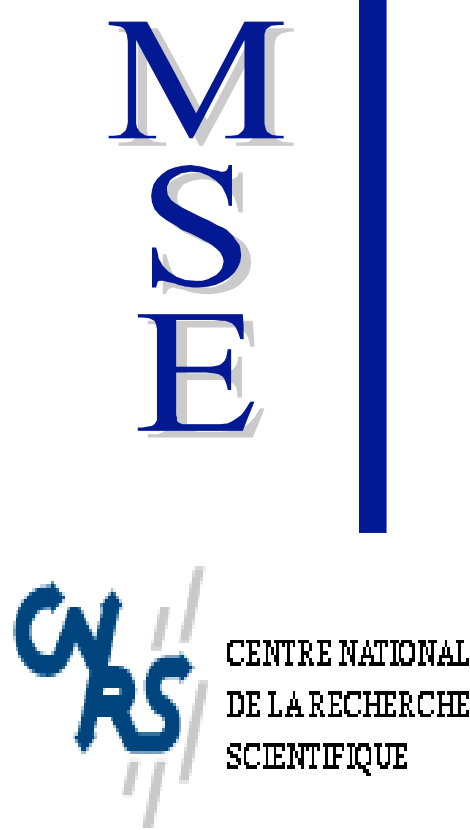


\title{
Functional Fragmentation and the Location of Multinational Firms in the Enlarged Europe*
}

\author{
Fabrice Defever ${ }^{\dagger}$
}

\begin{abstract}
Despite the recent advances in the theory of location, the analysis of the role of services surrounding production activity has been largely neglected. This paper analyzes the colocation of a multinational firm's value chain in the enlarged European Union. Depending on its particular characteristics, each function (or activity) would favor different country characteristics. Opposing this dispersion force, vertical linkages between stages can encourage firms to co-locate different activities in the same country. We use recently collected individual firm data on almost 11.000 location choices for a 5 year period and 23 countries. We analyze the determinants of location choice for each activity, including sectoral and functional agglomeration variables. We also illuminate the co-location of functions at the firm level, specifically that of R\&D and production.
\end{abstract}

JEL classification: F23, L22, R3

Keywords: Functional fragmentation ; vertical linkages ; location choice.

Fragmentation fonctionnelle et localisation des firmes multinationales dans l'Europe élargie.

Malgré les développements récents de la théorie de la localisation, le rôle des activités de service liées à la production reste peu étudié. Ce papier analyse la localisation des différents éléments de la chaîne de valeur des firmes multinationales au sein de l'Union Européenne. Certaines forces telles que les avantages comparatifs conduisent à la dispersion des fonctions (où activités) entre les différents pays. A l'opposé, les liens verticaux entres les différentes étapes du processus de production au sein des firmes peuvent conduire les entreprises à co-localiser différentes fonctions dans le même pays. Nous utilisons une base de données de firmes individuelles récemment développée qui fournit plus de 11000 choix de localisation dans 23 pays. Nous analysons les déterminants de la localisation, notamment avec des variables d'agglomération sectorielle et fonctionnelle. Enfin, nous montrons que les liens verticaux conduisent les firmes à localiser leur production et leur R\&D au sein des mêmes pays.

Classification JEL classification: F23, L22, R3

Mots-clés: Fragmentation fonctionnelle ; liens verticaux ; choix de localisation.

\footnotetext{
${ }^{*}$ A study of the quality of the database and its management have been carried out at the Invest in France Agency (AFII) under the supervision of Fabrice Hatem and Edouard Mathieu. We thank them for their help with this task. We are also grateful to the consulting group Ernst \& Young, and more specifically to Barry Bright and Mark Hughes. I wish to thank the guest editors and the three anonymous referees whose suggestions improved the paper greatly. I am also grateful to Carlo Altomonte, Céline Azemar, Gábor Békés, Matthieu Crozet, Rodolphe Desbordes, Gilles Duranton, Fabian Gouret, Keith Head, Philippe Martin, Giordano Mion, Thierry Mayer, Jean-Louis Mucchielli, Beata S. Javorcik, Eric Strobl, Deborah Swenson, Farid Toubal, Julien Vauday and the participants at seminars in Paris 1 Panthéon Sorbonne University (TEAM and ROSES), Dauphine University, PSE lunch seminar, at the conferences SMYE 2004 (Warsaw), GEP 2004 (Nottingham), EIIE 2004 (University of Ljubljana, Slovenia), RIEF 2004 and RIEF Doctoriales 2004 (Paris), AFSE 2004 (Paris), SIEPS workshop 2004 (Stockholm), HWWA 2004 (Hamburg), CEPR 2005 (Glasgow), CESifo 2005 (Venice), EEA 2005 (Amsterdam) and Econometric Society 2005 (ESWC London) for very helpful comments and discussions. The usual disclaimer applies.

${ }^{\dagger}$ TEAM-CNRS. University of Paris 1 Panthéon-Sorbonne, 106-112 boulevard de l’Hôpital, F-75647 Paris Cedex 13, France. Mail : fabrice.defever@malix.univ-paris1.fr
} 


\section{Introduction}

The fragmentation of the production process is now a major theme in research in International Economics. However, this research is still restrictive since it mainly considers the manufacturing or industrial aspects of fragmentation and the underlying globalization process. Krugman (1995) argues that the international value-chain decomposition is one of the four major aspects of modern international trade theory. He calls it "slicing up the value chain" and includes in its definition a large number of service activities. The international fragmentation carried out by multinational organizations should not be limited to that of the industrial process. We use the terminology "function" to refer to a stage or an activity which is part of the firm's value chain, and where the production stage itself only accounts for one stage ${ }^{1}$. As described by the World Investment Report (UNCTAD, 2002, pages 121-123): “[I]nternational production systems have emerged within which TNC's locate different parts of the production processes, including various services functions, across the globe [...] [T]he organization and distribution of production activities and other functions in what is commonly known as the global value chain. It extends from technology sourcing and development, production, to distribution and marketing."

Feenstra (2003) notes that this aspect of globalization has not been widely studied except in economic sociology and geography ${ }^{2}$. Despite the recent advances in location theory, ${ }^{3}$ existing studies only consider production plant location choices and largely neglect all service functions surrounding production activity. More generally, very few theoretical or empirical papers directly analyze the internationalization of service activities. One reason may be that while it is a very interesting research issue, it is also more complex to study due to the lack of data and the difficulties in linking it to theory. Thus, it is not surprising that, to our knowledge, the location of a broader range of multinational firm functions has never been econometrically tested. This paper attempts to fill this gap in the economics literature.

First introduced by Jones and Kierzkowski (1990), the theory related to the fragmentation phenomenon has been given a number of different names ${ }^{4}$. Multinational firms play an important role in this process through the vertical separation of activities, in order to exploit international factor-cost differences or through horizontal investments, where production plants are duplicated in several countries to get access to other markets ${ }^{5}$. Unfortunately, until now,

\footnotetext{
1 This terminology has been previously used by Duranton and Puga (2005).

2 See Gereffi and Korzeniewicz (1994) and Kenney and Florida (1994) in economic sociology and Dicken et al. (2001) and Yeung (2001) in geography.

3 See Head et al. (1995), Head and Mayer (2004).

4 Including de-location, disintegration of production, fragmentation, global production sharing, offshoring.

${ }^{5}$ On the former, see Helpman (1984). On the latter, see Markusen (1984) and Brainard (1997).
} 
empirical research has had difficulties in demonstrating the validity of this classification. In fact, as noted by Grossman et al. (2003) "[W]ith more countries and more stages of production, some organizational forms do not fit neatly into either of these categories".

A few recent papers have underlined the organizational complexity of multinational firms. Yeaple (2003) considers the common classification into two types of investment, horizontal and vertical, as highly restrictive when compared to the diversity of multinational location strategies. Neary (2002) and Ekholm et al. (2003) highlight the importance of export platforms. Hanson et al. (2001) argue that a distinction has to be made between production-oriented and distribution-oriented investments, where this choice does not reflect the export-versus FDI decision common to standard models in the literature, since the latter is only about alternative production modes. Our contribution is to focus on the role of pre- and post-production services activities which are thus widely neglected by the existing theories of fragmentation.

We aim to shed light on the determinants of the location of different parts of the firm's value-chain. To do that, we use a unique data set recently collected by the consulting group Ernst \& Young. Data of almost 11000 location choices was collected at the individual firm level covering the period 1997 to 2002. We consider non-European firms' investments in both the "old" European Union (EU) countries and the new accession countries. In fact, EU enlargement is a unique event in the process of studying the fragmentation of the production process across countries.

We discuss the likely location choice of the different stages taking into account their need for high skill or low skill workers and their wish of being located near the market. Multinational firms decide on the location choice of each stage by considering country characteristics, such as factor costs and/or market size. Comparative advantage differences across countries could lead to a spread of value chain activities, and the market access motivation could lead to the duplication of some of these activities. In addition to country characteristics, we follow the existing location choice theory and consider the influence of previous multinational firms' investments in a location. Consistently with the Duranton and Puga (2005) model, we find that service activities are sensitive to the functional aspect but not to the sectoral dimension. For production plants, the sectoral dimension remains very important.

Finally, we consider that firms could locate different stages of their value-chain near each other in order to save coordination costs and to benefit from complementarities. We analyze empirically the within-firm location of different stages of the value chain. We show that related activities are concentrated in a specific country due to vertical linkages between functions. This 
is the case between $R \& D$ and production plants, where both activities seem to have a strong attraction to one another. Surprisingly, the location of headquarters does not appear to have an impact on the location choice of any other part of the value chain.

The remainder of the paper is organized as follows: In section 2, we develop the theoretical model. Section 3 discusses the econometric model. Section 4 explains the database and variables used. Section 5 presents the econometrics results, while section 6 concludes.

\section{Theoretical discussion}

Our study is designed to analyze the location determinants of the different stages of multinational firms' value chain. Considering the firm's value chain implies that the following stages are taken into account: service activities surrounding the production stage, which include upstream stages or pre-production activities such as headquarters (HQ) or research \& development (R\&D) centers, and also downstream stages such as the service activities associated with the direct sales to the consumer, i.e. logistics and sales \& marketing activities.

The Knowledge-Capital Model (Markusen, 2002) provides a synthesis of the international organization of the multinational firms' production process. Allowing for vertical fragmentation, firms can locate their headquarters and their production in a different country. In this model, headquarters location is chosen solely on the basis of factor price, whereas the location of the single plant depends both on factor prices and market size. The model also allows for horizontal investments where firms can undertake the production activity in multiple countries, in order to save transport costs.

But considering service activities greatly complicates the analysis. More precisely, preproduction and post-production activities cannot simply be integrated in a two country model assuming a set of final goods. Exploring different models which could explain the recent increase in service offshoring, Markusen (2005) mentions some of the reasons why it is difficult to explain white collar services (re)location using current models: "One is that they may be firmspecific rather than bought and sold on arm's-length markets. Another is that they may form part of a particular production sequence, such as being a well-defined upstream (design) or downstream (after sales service) component of overall production. A third is that there may be crucial complementarities among different elements of the production chain [...] ". 


\subsection{Country characteristics}

Considering first the interaction between country and stage characteristics, it seems reasonable to believe that relatively skilled-labor intensive stages would be located in the most skilledlabor abundant countries. Maurin and Thesmar (2004), who study the occupational structure of French manufacturing firms, show that workers working in service activities are more skilled than those associated with production. So, it seems reasonable to consider both upstream and downstream service activities as intensive in high skill labor and the production stage as low skill labor intensive.

In addition to these two factors, we will consider that the countries' judicial quality could be an important factor in explaining the functions' location. More specifically, strategic functions such as headquarters or R\&D activities could be highly sensitive to the legal environment with regard to contracts ${ }^{6}$.

In the Knowledge-Capital Model (Markusen, 2002), while production plants face a tradeoff between low variable cost and high market access, the location choice of service activities, such as headquarters, is only based on countries' factor endowments. However, the relationship between market size and service activities location is probably more complex. As noted in the Markusen (2005) quotation (see above), service activities surrounding production process can be well-defined as upstream or downstream, leading to a specific relationship for each sequence of the value chain with the market. So, location of downstream activities could be viewed as highly related to the market size and therefore, this stage is necessarily located near final consumers. Alternatively, upstream activities don't sell anything to consumers, so their location could then be viewed as independent of the market. But even in the latter case, the literature has developed several arguments explaining the importance of the market size for upstream activities ${ }^{7}$.

\subsection{Functional versus sectoral agglomeration}

Head et al. (1995) have also considered the previous location of multinational firms as an im-

\footnotetext{
${ }^{6}$ For example, in an incomplete contract framework, Antràs (2005) consider that headquarters input can not be relocated in the South because of the weak protection of property rights in low-wage countries.

7 Notably, the literature relative to the internationalization of the R\&D centers by multinational firms Kuemmerle (1997) considers that this establishment can be dedicated either to the creation of new products or to the adaptation to the local market of existing products. Regarding the latter, market size could be an important feature of R\&D location choice. Another explanation for the importance of market size for the location of upstream stages has been considered by Holmes and Stevens (2004). In an urban economic framework, they consider that service activities could face intermediate transport costs due to the necessity of face to face relationships.
} 
portant factor in order to explain location choice. In fact, much evidence suggests that firms belonging to the same sector tend to cluster in the same regions or countries. While the sectoral aspect make sense when considering the choice of the location of production plants, this is much less clear when considering the service function, as emphasized by Duranton and Puga (2005). In an urban economics framework, these authors consider the transformation of urban structures from mainly sectoral to mainly functional specialisation. In fact, the separation of firms' activities should generate a new form of city specialisation based on function. Services are more likely to be located in big cities and production plants in small and low wage cities. The Duranton and Puga (2005) model then predicts that production plants would be more likely to be affected by the sectoral dimension and service functions by the functional one.

Therefore, in our study of the location choice, two forms of agglomeration could arise. The former is sectoral: activities belonging to the same sector are located in a specific country. More precisely, we will consider the agglomeration around production plants in the same sector. The latter is functional: activities belonging to the same function but not to the same sector are taking place in the same location.

\subsection{Co-location of activities}

Country characteristics are not the only element to determine the location choice of each element of the value chain. As noted by Markusen (2005) service activities are likely to be firm-specific rather than bought and sold on arm's-length markets, and there may be crucial complementarities among different elements of the production chain. Then, if each stage of the value chain is produced apart from the other stages, firms would probably face additional costs due to the need for coordination and the loss of complementarities between stages. This could lead to co-location between functions within the same country due to vertical linkages between stages.

Vertical linkages and within-firm co-location have already been proved to be prevalent. Notably, in a study on the location determinants of Japanese firms in the United States, Head et al. (1995) have shown the strong co-location of affiliates in the same region, due to the vertical linkages between affiliates within a Japanese group known as a Keiretsu. Nevertheless, Smith and Florida (1994), as one of the first, explicitly consider relationships between two distinct parts of the production process. They study the investment of Japanese auto-related parts suppliers and show that they tend to locate near Japanese assembly plants. A more recent paper by Chung and Song (2004) shows the sequential nature of investment of Japanese electronics firms in the United States. Prior investments of a firm seem to strongly influence the location 
choice of its subsequent investments.

\section{Econometric Model}

\subsection{Basic methodology}

In order to estimate the model, we use individual firm location choices and study the location of multinational firm investment in 23 European countries ${ }^{8}$. The most commonly used econometric modelling technique for this type of problem is the conditional logit model (CLM) proposed by McFadden (1984). Each location decision is a discrete choice made among several alternatives.

While the true profits, yielded by alternative locations, cannot be observed, one does observe the actual choice of each firm and the characteristics of the alternative locations. Suppose $R=(1, \ldots, r, \ldots o)$ is the set of possible location countries. Each location offers a profit of $\pi_{r}$ such that

$$
\pi_{r}=U_{r}+\varepsilon_{r}
$$

with

$$
U_{r}=\beta X_{r},
$$

where $U_{r}$ depends on observable characteristics $\left(X_{r}\right)$ of each location choice $r, \beta$ is a vector of coefficients to be estimated by maximum likelihood procedures and $\varepsilon_{r}$ is the unobservable advantage of the location $r$. The firm will choose $r$ if the profit at this location is higher than those obtained in any other alternative location. Hence, the probability of choosing $r$ is :

$$
P_{r} \equiv \operatorname{Prob}\left(\pi_{r}>\pi_{k}\right)=\operatorname{Prob}\left(\varepsilon_{k}<\varepsilon_{r}+\beta\left(X_{r}-X_{k}\right)\right), \forall k \neq r .
$$

\subsection{Limitations of the conditional logit}

The crucial assumption of the CLM is that the error terms are independently and identically distributed according to a type I extreme value distribution. It leads to the simple probability of choosing location $r$

$$
P_{r}=\frac{e^{\beta X_{r}}}{\sum_{i=1}^{o} e^{\beta X_{i}}}
$$

\footnotetext{
8 These are EU countries and the new EU member countries that entered EU in May 2004, excluding Malta and Cyprus.
} 
One of the main assumptions of CLM has to do with the Independence of Irrelevant Alternatives (IIA), which implies that choosing one country is independent of the destination choice set: working on a sub-sample or on the whole enlarged European Union should produce the same results (except of course for the loss of information in the omitted location decisions). But unobserved characteristics of the choosers and unobserved correlations across element choices can cause a violation of the IIA assumption (Train, 2003). In such a case, estimations of logit models are inconsistent. The use of the specification test proposed by Hausman and McFadden (1984) shows that the IIA assumption is violated, due to individual heterogeneity which can lead to a disturbance of the distribution of the errors and inconsistency of the estimators.

\subsection{Mixed logit}

One way to relax the IIA assumption is to introduce individual random effects and to estimate a mixed logit model (MLM) (Brownstone and Train, 1999) .

The utility of person $l$ from alternative $\mathrm{r}$ is specified as: $\pi_{l r}=\beta_{l}^{\prime} X_{l r}+\varepsilon_{l r}$ where $X_{l r}$ are observed variables that, in our case, relate to the decision-maker, $\beta_{l}$ is a random vector of coefficients which vary over decision-makers in the population with density $f(\beta)$ and $\varepsilon_{l r}$ is a random term with the same properties as in the CLM. Thus, we can write the utility map as:

$$
\pi_{l r}=\beta^{\prime m} X_{l r}+\beta_{l}^{\prime s} X_{l r}+\varepsilon_{l r},
$$

where $\beta^{m}$ and $\beta^{s}$ characterize the distribution of $\beta$, i.e., its mean and deviations. Following Train (2003), the unconditional choice probability is:

$$
P_{l r}=\int\left(\frac{e^{\beta^{\prime} X_{l r}}}{\sum_{i=1}^{o} e^{\beta^{\prime} X_{l i}}}\right) f(\beta) d \beta .
$$

We estimate $\beta^{m}$ and $\beta^{s}$ with simulation methods, assuming that $f(\beta)$ is normal ${ }^{10}$. Variables directly linked to firms would be considered as fixed coefficients ${ }^{11}$. This methodology will allow us to eliminate differences in location choices of the multinational firms due to their

\footnotetext{
${ }^{9}$ Introducing fixed effects at the country level removes some forms of bias that might arise. Unfortunately, our data only covers a five year period, and so variables defined at the country level do not remain significant. Another way to relax the IIA assumption is to use a nested logit model as Head and Mayer (2004). Unfortunately, no geographical structure seems to be relevant simultaneously for all parts of the value-chain. So, this would have introduced difficulties when comparing results for each function. Another solution could have been to implement a count data model. Notably, Guimarães et al. (2003) demonstrate the close relationship between the conditional logit and poisson model. The advantage of the latter is that it is not related to the IIA assumption. Unfortunately, this methodology aggregates the individual firm data, and does not allow the study of individual firm characteristics, as within-firm co-location variables.

${ }^{10}$ Estimations would be obtained considering 250 simulations.

${ }^{11}$ In fact, introducing heterogeneity among firms around a firm's specific variables would not make sense.
} 
heterogeneity. In fact, we do not want this aspect to affect estimators directly linked to country characteristics.

\section{Data}

\subsection{Description of the database}

The theory will be evaluated by econometric tests based on our database of multinational firms' new location in Europe over the period 1997-2002 covering more than 11000 projects ${ }^{12}$.

The EIM (European Investment Monitor) database which has been developed by the consulting group Ernst \& Young, identifies the project-based foreign inward investment announcements that are new, expanding, or co-located in an international context. The main sources of information are newspapers, financial information providers (such as Reuters), and national investment agencies (such as the Invest in France Agency ). When the consulting group discovers a new project, they track it in order to determine the exact location at the city level. Projects included in the database have to comply with several criteria to be considered as international investments. The database excludes acquisitions, license agreements, and joint ventures (except in the case where these operations lead to an extension or a new establishment). It also excludes retail, hotel and leisure facilities, fixed infrastructures, extraction facilities, and portfolio investments. There are no minimum investment size criteria, but the number of investments where less than 10 jobs are created, turns out to be very low.

The investment project data are at the individual firm level and the data provide information on investments made in our sample of European countries by European and nonEuropean firms, except for investments in the home country. It includes the name of the firm, the parent company name, the name and the origin country of the parent company, the sector and both the country and the city of location. It also includes the function of each investment (unit of production and different service activities, such as headquarters, research \& development centers, logistics, or sales \& marketing offices).

At the country level, table 1 shows that the number of investments in the production activity is less than one half of the total number of investments realized by multinational firms. One would expect that the fragmentation of the production process drives the different parts of the value chain to be located in accordance with countries' characteristics. From the same table,

\footnotetext{
12 The complete database is composed of 13109 projects when one considers all countries and functions available. To simplify our presentation, we will limit our descriptive statistics to the 23 countries of the enlarged Europe and to five functions. This restriction will be further discussed in section 4.2.
} 
Figure 1: Number of investments by function as a share of the countries' population in the Enlarged Europe.

Map 1 : Headquarters location per cap

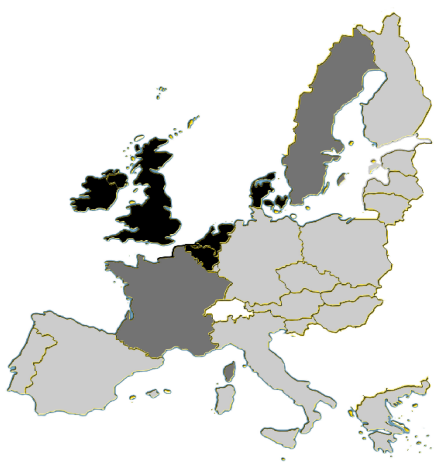

Map $2:$ R\&D centers location per cap

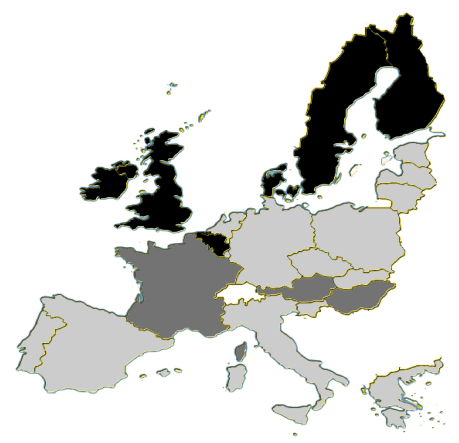

Map 3 : Production units location per cap

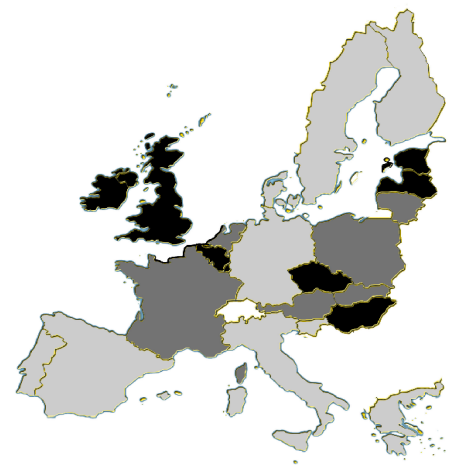

Map 4 : Logistic plants location per cap

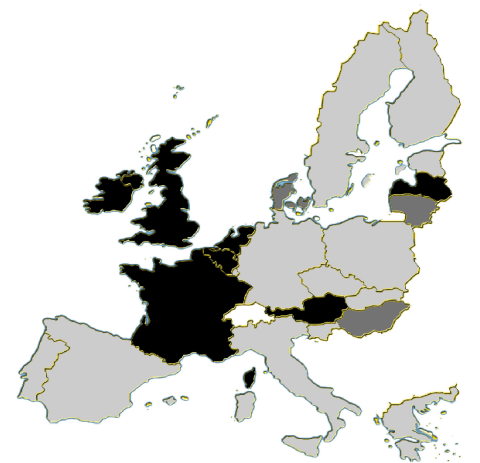

Map 5 : Sale \& marketing location per cap

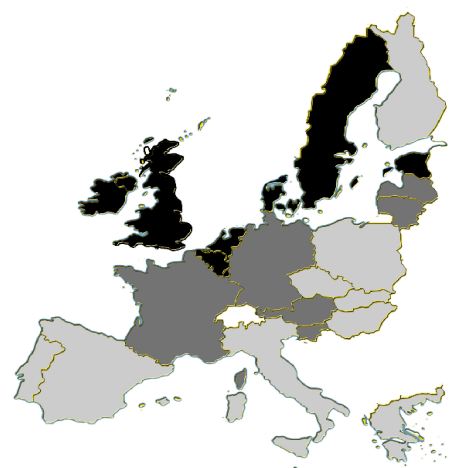

Number of investments $30 \%$ above the European average

Number of investments between $30 \%$ and $-30 \%$ around the European average

Number of Investments $30 \%$ below the European average

Notes: New creations and extensions of European and non-European firms in the manufacturing sector in the 23 countries of the Enlarged European Union (EU15 and CEE8) during the period 1997-2002. 
we can observe that production investments in Central and Eastern Europe (CEE8) countries ${ }^{13}$ represent $72 \%$ compared to $42 \%$ in the EU 15 . Figure 1 shows maps of the geographical distribution of the five functions (headquarters, $R \& D$, production, logistics and sales \& marketing office) during the period 1997 to 2002. To correct for size, we consider the number of investments for each function divided by the countries' population. Some countries such as the UK, Ireland or Belgium, relative to their population size, attract a total number of investments that is 30\% above the European average for all the functions. At the opposite end, Portugal, Spain, Italy and Greece, and again as a share of their population size, attracted a total number of investments that is $30 \%$ below the European average for the five functions.

Table 1: Structure of the investments by function in EU15 and CEE8

\begin{tabular}{||lccc||}
\hline \hline Function & European Union & Accession (CEE8) countries & Total \\
Headquarters & 840 & 19 & 859 \\
Research \& Development & 946 & 56 & 1002 \\
Production & 3912 & 1304 & 5216 \\
Logistics & 816 & 142 & 958 \\
Sales \& Marketing & 2849 & 299 & 3148 \\
Total & 9362 & 1820 & 11182 \\
\hline \hline
\end{tabular}

Notes: New creations and extensions in the 23 countries of the Enlarged European Union (EU15 and CEE8) on the five functions during the period 1997-2002. Manufacturing and non-manufacturing sectors. European and non-European firms.

At the firm level, of the 5166 parent companies that have created new establishments in the enlarged EU during the period 1997-2002, 4008 have created new establishments for only one function. For the rest of the sample, 636 firms have realized investments in two types of activities, 225 in three, 90 in four and 207 have invested in all five functions studied. Some firms have realized an impressive number of investments. For example Ford Motor Co, had 37 new establishment announcements in the enlarged EU during the period 1997-2002 ${ }^{14}$.

\subsection{Construction of the dependent variable}

We will introduce a restriction on the data set in order to obtain a coherent and homogeneous subset. Notably, we are able to distinguish projects between real creations (also known as greenfield) and extensions (e.g. brownfield) ${ }^{15}$. This latter category is not directly linked to the location choice determinants. Consequently, we only utilize real creations for the construction of the dependent variable.

\footnotetext{
${ }^{13}$ CEE8: Czech Republic, Estonia, Hungary, Latvia, Lithuania, Poland, Slovakia, Slovenia.

142 headquarters, 5 R\&D centers, 22 production plants, 1 logistics center and 7 sales \& marketing offices.

15 The database computes 7892 new establishments and 3290 extensions during the period 1997-2002 in the 23 countries of the enlarged Europe and the five functions.
} 
Delimitation of the functional area: We only consider five functions : production plant, headquarters, R\&D centers, logistics, sales and marketing office. Other functions are available ${ }^{16}$ but we could not use them due to the limited number of investments.

1. Headquarters : This function corresponds to all the administration, management and accounting activities localized internationally. It includes decision centers, but our data does not allow us to know exactly their importance in the global decision process and none correspond to the principal decision center. In fact, investments realized in the home country are not considered in our dataset. Most of these centers correspond to European or regional headquarters or are only intended for the network organization at a national level.

2. Research \& Development centers : This function is be related to fundamental scientific research, but also to applied development directly linked to the production process. We cannot distinguish between centers dedicated to the development of new products or to the adaptation to the local market of existing products.

3. Production plants: This corresponds to the whole entity related to the physical production of goods.

4. Logistics : This function refers to all the entities linked to goods transport, including warehousing (e.g. regional good distribution). They can be internal to the firm or external logistics, involved in distribution to customers or with suppliers. It can also be viewed as acting as an intermediary between component production and assembly.

5. Sales \& marketing offices: This function includes both wholesale trade and business representative offices. Despite the fact that they are not limited by size, it seems that the database only covers the largest investments.

We group functions under three headings : upstream activities ( i.e. headquarters and research \& development), production plants and downstream functions (i.e. marketing, sales and logistic services).

Delimitation of the sectoral area: Each project can be defined by sector or by function. There are 49 sectors classified by the NACE classification ${ }^{17}$, with sub-sectors in the automotive, electric-electronic, and the chemical sectors. We only consider the manufacturing sector and exclude other sectors (essentially services sectors), see table $2^{18}$.

${ }^{16}$ Contact center ; education \& training ; internet data center ; testing \& servicing ; service center. These functions represent 770 projects.

17 Classification of Economic Activities in the European Community.

18 This also means that we consider the service function of a manufacturing sector, for example, the headquarters of an automotive company, but through the exclusion of the services sector we do not consider any project of the services sectors, for example, the headquarters of a financial sector firm. 
Table 2: Structure of the investments by function and by sector type

\begin{tabular}{||ccccccc||}
\hline \hline & Headquarters & R\&D & Production & Logistics & Sales office & Total \\
Manufacturing & 395 & 727 & 5104 & 541 & 845 & 7612 \\
Non-manufacturing & 464 & 275 & 112 & 417 & 2303 & 3570 \\
Total & 859 & 1002 & 5216 & 958 & 3148 & 11182 \\
\hline
\end{tabular}

Notes: New creations and extensions in the 23 countries of the Enlarged European Union (EU15 and CEE8) on the five functions during the period 1997-2002. European and non-European firms.

Delimitation of the geographical area : The database indicates the home country of each investing firm (see table 3). We only consider investments realized by non-European firms (mostly American and Japanese firms) and exclude all European and Russian firms' projects in order to exclude vertical investments and only consider horizontal and export platform investments. In fact, we would like to study location choices independently of the home country characteristics ${ }^{19}$. As host countries, the database includes western and eastern European countries, including Russia and Turkey, in total we have data on 36 countries. Unfortunately, due to the lack of homogeneous and comparable data at the national level, we thus only consider as possible location choice 23 countries including the EU members that entered the EU in May $2004^{20}$.

Table 3: Structure of the investments by function and origin region

\begin{tabular}{||lcccccc||}
\hline \hline Origin region & Headquarters & R\&D & Production & Logistics & Sales office & Total \\
$E E A^{a}$ & 211 & 354 & 2883 & 562 & 1144 & 5154 \\
$N A F T A^{b}$ & 515 & 525 & 1646 & 273 & 1708 & 4667 \\
Japan & 58 & 99 & 451 & 64 & 123 & 794 \\
Other & 76 & 24 & 236 & 59 & 173 & 566 \\
Total & 859 & 1002 & 5216 & 958 & 3148 & 11182 \\
\hline \hline
\end{tabular}

Notes: ${ }^{a}$ The European Economic Area. ${ }^{b}$ The North American Free Trade Agreement.

New creations and extensions in the 23 countries of the Enlarged European Union (EU15 and CEE8) for the five functions during the period 1997-2002. Manufacturing and non-manufacturing sectors.

\subsection{The independent variables}

Testing the theoretical framework implies the consideration of three types of variables. First, we will study host country characteristics. More precisely, we consider high skilled and low skilled labor input (in terms of endowments and wages respectively) in addition to governance and market size variables. Second, we also consider functional and sectoral aspects according to the Duranton and Puga (2005) model. Finally, we introduce co-location variables between

\footnotetext{
${ }^{19}$ For example, considering European investments within Europe would have to imply that the distance between the home country and the location choice is taken into consideration.

${ }^{20}$ With the exception of Malta and Cyprus. The country limitation reduces the sample by 1189 projects to 11920 investments.
} 
functions, in order to consider national vertical linkages between stages of the value-chain.

\section{Country characteristics variables:}

Unit Wage Cost: This variable corresponds to the wage (per hour) divided by productivity (value added per head) both provided by Eurostat ${ }^{21}$. We calculate Unit Wage Cost for each host country and for the five different functions. To do that, we need to look into the correspondence between function and the NACE Rev.1 classification (see table 4) using data which are only available for the year 2000 .

Table 4: Relationship between function and NACE classification

\begin{tabular}{||llc||}
\hline \hline Function & Nace classification & Code \\
Headquarters & Financial activities & J \\
Research and development center & Financial activities & J \\
Production & Manufacturing & D \\
Logistics & Transport services & I \\
Sales \& marketing center & Sales sector & G \\
\hline \hline
\end{tabular}

Our theoretical framework predicts that the coefficient associated with this variable should be negative and significant for production plant, for which labor costs are the most important factor.

Education: As a proxy for high skilled labor, we consider the percentage of 20 to 29 year olds with a tertiary education (ISCED 225 and 6) in mathematics, sciences or technologies for the period 1997 to $2002^{23}$. In light of our theoretical discussion in the beginning of this paper, the location of service activities could more influence by the presence of local human capital, so we expect the a higher coefficient for the four service functions compared to the production activity. It is more ambiguous in the downstream stage, because on the one hand, it is a service activity, and on the other hand, due to high transport costs, the location of consumer-related functions could also be only determined by the market size.

Judicial Quality: As a way to consider specific political characteristics which could be important in the European countries, we use an indicator of the quality of the judicial system

\footnotetext{
${ }^{21}$ We assume identical within-function hours worked per year among countries. To our knowledge, no data of annual hours worked per capita are available at NACE rev.1 desegregation for all European countries in our sample.

${ }^{22}$ International Standard Classification of Education.

${ }^{23}$ Capturing the education level of the labor force is difficult. Notably, some cultural aspects play a major role. Specifically, the comparison of central European countries, which have been highly influenced by the communist system, with western European countries, is problematic. For example, with respect to secondary school enrolment in 2001, the fourth highest level countries are CEE8 countries and the ninth lowest are EU15 countries.
} 
computed by Kaufmann et al. (2004) for the year 1997 to 2002. The variable, called "rule of law", is established on the basis of polls of experts or surveys of businessmen/citizens. The variable is related to the perceptions of the effectiveness and predictability of the judiciary, and the enforceability of contracts.

Demand : We divided the demand variable between the internal market, using GDP in constant US\$ 1995, provided by Cepii (Chelem) for the year 1997-2002, and the "external market potential". The latter, inspired by Harris (1954), is the sum of the GDPs of all other countries weighted by their distance $D_{i j}$ to the chosen location. We use distance between capital cities as provided by the Cepii.

$$
\text { External Market Potential } i=\sum_{i \neq j}\left(\frac{G D P_{j}}{D_{i j}}\right) .
$$

The model predicts that demand coefficients should be positive and significant for downstream stages. Production is viewed as an intermediate stage. The relationship between upstream activities and market size is more ambiguous. In fact, the interpretation of GDP coefficient is difficult. In fact this variable is highly correlated with country population ${ }^{24}$ and could also be viewed as a size variable, with which the number of establishment locations would systematically increase.

Functional versus sectoral specialisation: We consider the functional and sectoral dimensions in each possible country. To compare the importance of these two aspects, we build two variables using the stock of investments realized by multinational firms for the years 1997 to 2002. We take into account all the projects of the sample (greenfield and brownfield). More precisely, we include all the established extensions (which represent about one third of the total number of projects) realized during the period 1997-2002 and which have not been created during this period ${ }^{25}$. This allows us to consider these investments as anterior investments, to which we will add the new establishment creations realized during the years before the specific investment studied. In this way, we are able to build the stock of investments ${ }^{26}$. Thus,

${ }^{24}$ The correlation between GDP and population is 81 percent.

25 A site extended in 2000 with no creation reported during the period 1997-2002 would be considered as anterior to 1997 . We have to be careful not to consider the same project more than once. For example, a production plant created in 1999 and extended in 2001 has to be treated as existing since 1999.

${ }^{26}$ We consider the stock of previous investments, while the previous literature was more likely to consider the number of investments during the year N-1 (a notable exception is Chung and Song (2004)). The main reason is due to the low number of investments realized in some functions (for example, in headquarters activity). For the same reason, we integrate non-manufacturing projects in our "functional variable" despite the fact that our dependent variable would only be defined for manufacturing sectors. 
the number of past investments is naturally growing with time. In order to study precisely the history of location of a specific site, we would have to consider for each function only one possible investment for each parent company and for each city ${ }^{27}$. Finally, we exclude all projects realized by affiliates of the parent company of the firm realizing the investment.

In order to consider the functional aspect, we build the variable Functional count which corresponds to the log of the stock (plus one $)^{28}$ of foreign establishments in the studied function in the country $r$ by all firms, excluding parent company affiliates, and for all sectors, excluding the sector of the investing firm, see table 5. Different from our dependent variable, we consider both manufacturing and non-manufacturing firms ${ }^{29}$. The sectoral dimension is considered through the variable Sectoral count which corresponds to the log of the stock (plus one) of foreign establishments in the production activity in the same sector as the investing firm in country $r$ by all firms (excluding parent company affiliates), see table 5. Following Duranton and Puga (2005), we expect that a production plant would be affected by the sectoral dimension, while service functions should be more likely to focus on the functional one ${ }^{30}$.

Co-location variables: Vertical linkages between the different stages of the value chain are likely to encourage multinational firms to co-locate functions in order to save coordination costs. In this study, we only consider national co-location. To do this, we build five "colocation" variables, one for each function $f$. We build the historic establishment, identically to the sectoral and functional variables, for each parent company and for each function in all countries $r^{31}$. The variable takes the value 1 if the function $f$ has already been previously carried out in the country by one of the affiliates of the parent company and 0 otherwise ${ }^{32}$. This allows us to consider vertical linkages between functions, which would lead to withinfirm co-location between activities in a specific country. This variable would be integrated as a fixed coefficient when implementing the mixed logit. In fact, the variable defined at the parent company level can be considered as specific to the firm.

\footnotetext{
27 We count as just one investment, all the projects in a specific function and in a particular city (the most detailed geographical level) for each parent company. For example, if a firm decides to locate two production plants in the same city, we only consider this investment once. This allows us to establish an investment history at the city level, and to avoid double counting. This methodology also serves to eliminate from our functional and sectoral variables the within-firm agglomeration of the same function at the city level.

${ }^{28}$ In order to consider the logarithm, even with zero investment, we add one

${ }^{29}$ For example, we would count in the stock of headquarters HQs the location of financial sector firms.

${ }^{30}$ It is possible to consider our sectoral and functional variables as reflecting agglomeration effect as in Head et al. (1995). They can also be considered as endogenous and only reflecting omitted variable bias. In this case, these variables would permit us to shed light on the functional and sectoral dimensions, not present in the other explanatory variables.

${ }^{31}$ In the case of a joint venture, we consider an investment for each parent company engaged in this investment.

${ }^{32}$ Considering simultaneous investment in a country of two or more activities could lead to endogeneity problems. For this reason we consider in our explanatory variable previous investments only. In addition, we implement five independent regressions to avoid interaction between possible simultaneous choices.
} 
Table 5: Dependent and independent variable definitions

\begin{tabular}{|c|c|c|}
\hline Variables & Definition & year \\
\hline $\mathrm{Y}$ & $\begin{array}{l}\text { Location choices among } 23 \text { countries (greenfield only) } \\
\text { of non-European firms from manufacturing sectors. }\end{array}$ & $1997-2002$ \\
\hline \multicolumn{3}{|l|}{ country variables } \\
\hline Wages & Labor cost per hour by function (Eurostat). & 2000 \\
\hline Productivity & Value added per worker by function (Eurostat). & 2000 \\
\hline Unit Wage Cost & Wage divided by productivity by function. & 2000 \\
\hline Education & $\begin{array}{l}\% \text { of } 20 \text { to } 29 \text { year olds with tertiary school level in } \\
\text { sciences, mathematics or technologies. (Eurostat). }\end{array}$ & 1997-2002 \\
\hline Judicial Quality & $\begin{array}{l}\text { Quality of the judicial system and of the contracting } \\
\text { environment (Kaufmann et al., 2004). }\end{array}$ & 1997-2002 \\
\hline \multirow[t]{2}{*}{ GDP } & Constant Gross Domestic Product: US\$ 1995 & 1997-2002 \\
\hline & (Cepii: Chelem). & 1997-2002 \\
\hline Distance & $\begin{array}{l}\text { Distance between home and host country capital cities } \\
\text { (Cepii). }\end{array}$ & \\
\hline External Market Potential & $\begin{array}{l}\text { Summation of country GDPs of all countries weighted } \\
\text { by their distance to the location choice. }\end{array}$ & $1997-2002$ \\
\hline \multicolumn{3}{|c|}{ Functional and sectoral dimensions } \\
\hline Functional count & $\begin{array}{l}\text { Stock (plus one) of firms location in the same function } \\
\text { but not in the sector of the investing firm. } \\
\text { (greenfield and brownfield). }\end{array}$ & 1997-2002 \\
\hline Sectoral count & $\begin{array}{l}\text { Stock (plus one) of production plant in the same sector } \\
\text { as the investing firm. } \\
\text { (greenfield and brownfield). }\end{array}$ & $1997-2002$ \\
\hline \multicolumn{3}{|l|}{ Co-location variables } \\
\hline Function Co-location & $\begin{array}{l}1 \text { if function } f \text { have been located in the past and } \\
0 \text { otherwise (greenfield and brownfield) }\end{array}$ & $1997-2002$ \\
\hline
\end{tabular}

\section{Econometric testing}

Tables 6 to 8 summarize results of non-European firm location choices during the period 19972002 in the 23 countries of the enlarged European Union. Each table contains 5 independent regressions ; one for each of the five functions ${ }^{33}$. We implement both conditional logit (tables 6 and 8 ) and mixed logit (tables 7). We begin with the study of country determinants as well as functional and sectoral aspects and then the co-location variables. All country variables are in $\operatorname{logs},^{34}$ which enables us to consider the coefficients to be a relatively precise approximation of the elasticity of the probability of choosing a particular country with respect to the considered variable for the average investor. In table 8 we will introduce a country fixed effect in a CLM with the vertical co-location variables between functions.

\footnotetext{
${ }^{33}$ We have also estimated the five regressions simultaneously. It provides basically the same results using conditional logit, but we had difficulties in implementing it using mixed logit due to computational limitations.

${ }^{34}$ Including the Education variable, whose coefficient would be interpreted as a percentage variation.
} 


\subsection{Country Characteristics}

The comparison of country determinant coefficients across the different sequences of the value chain will enable us to gain insight as to the possibility of function specific effects. The Mixed Logit Model (MLM) (table 6) mostly provides the same results as the CLM (table 7) on the country characteristic variables.

In line with the theoretical discussion, unit wage costs have a negative and significant coefficient on production plant and a non-significant one for service activities. For the latter, the both the education or governance level at a location are relevant, but each in a distinctive manner. Location of upstream activities is influenced by the quality of the legal system while it is not influenced by the education level. This result, which seems surprising at first, is plausible if we consider as quasi-similar the education level in the CEE8 and EU15 countries. In this case, the judicial quality and contract environment seem more suitable for explaining the extremely low number of locations of the headquarters and R\&D functions in the CEE8 (see table 1). The location of downstream stages seems, however, to be better explained by the level of education rather than the governance level. The significant and large coefficients show that downstream stages' location choices are not fully determined by the size of the market and their locations can be influenced by higher education levels.

Turning to the demand variable, GDP coefficients are positive and significant at the 1 percent level for all service activities. This finding is difficult to interpret. In fact, this variable can be viewed as representing the demand size as well as a proxy for country size. It could also be an important factor for upstream activities, notably for R\&D location, as noted by Kuemmerle (1997). Even more surprisingly, the production location choice is not influenced significantly by GDP ${ }^{35}$. A more accurate market size variable could be the use of the External Market Potential. The coefficient for this variable is in line with our expectation: for location of downstream functions this demand variable is of great importance ${ }^{36}$. In contrast, decisions on the $R \& D$ location are not determined by external market potential, but for the production plant location the external market potential is again relevant. The only function that behaves

\footnotetext{
${ }^{35}$ This result contrasts with previous studies on production plant location, notably Disdier and Mayer (2004) for French investments in eastern and western European countries. Instead of the stock of investments, most location theory studies include as agglomeration variable the number of foreign investments in the previous year. Using this methodology, we obtain a significantly positive coefficient associated with GDP (with mean around 0.20). Unfortunately, when dealing with service activities, which only count for a small number of establishments, the stock of previous investments is better suited.

${ }^{36}$ Another way of considering the international orientation of countries could have been in the use of a "trade openness" variable. Such a variable can simply be defined as the export plus import of each country divided by their GDP. Keeping all other variables unchanged, the introduction of this variable did not affect previous results. The variable was insignificant for all activities except for logistics, for which the coefficient was significant at the $1 \%$ level.
} 
differently than predicted w.r.t. market potential is the headquarters function, which obtains a high coefficient significant at 10\%. This result contrasts with Davis and Henderson (2004) who study headquarters location at the city level in the United States. In their study, the market potential variable does not affect HQ's location choice. The necessity of a strategic and central location to manage its international networks could explain the significance and size of the external market potential coefficient for the HQ function. It significance could also be due to an omitted variable like corporate tax rates $^{37}$.

\subsection{Functional versus sectoral specialisation}

We now turn to the functional and sector aspects. In line with the Duranton and Puga (2005) model, the sectoral count variable is significant and positive for the production plant location choices, and non- or weakly significant with low values for service functions. In this respect, logistics seems to act as a production activity, and is mainly driven by sectoral aspects. Except in the logistics case, the functional count variable seems to be an important variable for all service functions in line with our expectations ${ }^{38}$. At the urban level, other studies on the location determinants of headquarters in the Unites States have come up with mixed results. Notably, Davis and Henderson (2004) show that the presence of headquarters has a positive impact on headquarters location choice. On the other hand, Strauss-Kahn and Vives (2005) show that location choice is highly dependent on the employment and other HQ locations in the same industry.

\subsection{Functional co-location and the networks' firms}

Previous econometric studies of the determinants of production plants' location have already been found agglomeration effects and vertical links between or within firms to be essential. Head et al. (1995), using Japanese investments in the United States consider possible supply re-

\footnotetext{
37 We have corporate tax rates for the year 2000 using data from the Office of Tax Policy Research (www.otrp.org). Unfortunately, they only provide data for 19 countries on the 23 of the sample. For the four other countries, we have used data from official sources of each country. Introducing the corporate tax variable on HQs location choice leads to a non-significant external market potential coefficient. The tax coefficient is (unexpectedly) positive and significant (10\%) for HQs. It is negative at $10 \%$ for Sales \& Marketing and non-significant for all other functions.

38 We also considered an English language variable. (i) we introduced dummies for North-American investments in Ireland and in the United Kingdom. (ii) We used "output" data on English language skills (\% of the population who speaks English well enough to take part in a conversation), provided by Eurobarometer survey published by the European Commission. We interacted this variable with a North-American investments dummy. It is interesting to note that the second variable (output on English language) is correlated at $70 \%$ with the legal quality variables. In both cases, the variables (i) and (ii) were non-significant for $H Q, R \& D$ and logistics and were positive and significant for production and Sales \& Marketing. In both cases, all results remain relatively unchanged except for the functional count variable for headquarters' location choice. For this function, the functional stock variable always becomes insignificant. This result comes from the fact that half of all HQs are located in the UK, and that $70 \%$ of the HQs located in the UK are American.
} 
lationships or technological spillovers between members of the same industrial Keiretsu. Smith and Florida (1994) explicitly considers relationships between two distinct parts of the production process. They show that Japanese auto-related parts suppliers tend to locate near Japanese assembly plants.

The contribution of this section is the study of co-location variables between functions within the same parent company in a specific country. As mentioned, in the econometric model we estimate $\beta^{m}$ and $\beta^{s}$ with simulation methods, assuming $f(\beta)$ is normal for all variables which are not firm level characteristics. This does not include our co-location variables, which would be considered as fixed coefficients. We do not include the diagonal of the subdivided network variables (for which setting up a function $f$ would have been explained by the presence of the same function by other affiliates). In fact, we are more interested in vertical linkages rather than within-function co-location. Both CLM and MLM agree with the two main results of this section: (i) within-firm vertical linkages tend to locate services activities in the same country as production plants. (ii) R\&D centers and production plants seem to be strongly attracted by each other. To show the robustness of this results, table 8 presents CLM with country fixed effects. Co-location variables are defined for the year and parent company in each country and so remain unchanged ${ }^{39}$.

The four service functions surrounding production are all attracted by the production location. R\&D and logistics have high and significant coefficients associated with production co-location variables while headquarters and sales \& marketing are only weakly significant. It is interesting to note that service functions are attracted by the production plant when one is looking at vertical linkages inside the firm. In fact, apart from logistics, the sectoral count variables do not seem to have an impact on their location. These results could lead to the hypothesis that functional specialisation arises with the fragmentation of the production process, and sectoral specialisation when within-firm vertical linkages are strong and tend to make firms co-locate their different functions in the same country.

The second important result of the introduction of vertical linkage variables is the colocation between R\&D and Production plants. In fact, those functions are highly attracted to each other and the strong vertical linkages between activities are likely to lead to a cumulative effect such as described in the New Economic Geography literature (Krugman and Venables,

\footnotetext{
39 Unfortunately, our dependent variable is only defined for a small period of time. So, including country fixed effects would make an explanatory variable defined only at the country and time level to be insignificant.
} 
Table 6: Location choices and functional Co-location: Conditional Logit Model.

\begin{tabular}{|c|c|c|c|c|c|}
\hline \multirow[b]{2}{*}{ Variables } & \multicolumn{5}{|c|}{ Dependent Variable: Location choice } \\
\hline & Headquarters & R\&D & Production & Logistics & $\begin{array}{c}\text { Sales \& } \\
\text { Marketing }\end{array}$ \\
\hline Ln Unit Wage Cost & $\begin{array}{c}0.26 \\
(0.50)\end{array}$ & $\begin{array}{l}-0.11 \\
(0.30)\end{array}$ & $\begin{array}{l}-0.66^{a} \\
(0.24)\end{array}$ & $\begin{array}{l}-0.75 \\
(0.50)\end{array}$ & $\begin{array}{c}0.19 \\
(0.19)\end{array}$ \\
\hline Ln Education & $\begin{array}{c}0.27 \\
(0.27)\end{array}$ & $\begin{array}{c}0.12 \\
(0.19)\end{array}$ & $\begin{array}{l}-0.34^{a} \\
(0.10)\end{array}$ & $\begin{array}{l}0.63^{a} \\
(0.23)\end{array}$ & $\begin{array}{l}0.30^{b} \\
(0.12)\end{array}$ \\
\hline Ln Judicial Quality & $\begin{array}{l}1.03^{a} \\
(0.38)\end{array}$ & $\begin{array}{l}0.52^{a} \\
(0.20)\end{array}$ & $\begin{array}{l}0.27^{a} \\
(0.09)\end{array}$ & $\begin{array}{c}0.36 \\
(0.29)\end{array}$ & $\begin{array}{l}-0.07 \\
(0.14)\end{array}$ \\
\hline Ln GDP & $\begin{array}{l}0.46^{a} \\
(0.15)\end{array}$ & $\begin{array}{l}0.25^{a} \\
(0.08)\end{array}$ & $\begin{array}{c}0.03 \\
(0.07)\end{array}$ & $\begin{array}{l}0.53^{a} \\
(0.19)\end{array}$ & $\begin{array}{l}0.44^{a} \\
(0.06)\end{array}$ \\
\hline $\begin{array}{l}\text { Ln External Market } \\
\text { Potential }\end{array}$ & $\begin{array}{l}1.03^{b} \\
(0.49)\end{array}$ & $\begin{array}{l}-0.16 \\
(0.23)\end{array}$ & $\begin{array}{l}0.27^{a} \\
(0.10)\end{array}$ & $\begin{array}{l}2.04^{a} \\
(0.38)\end{array}$ & $\begin{array}{l}0.66^{a} \\
(0.16)\end{array}$ \\
\hline Ln Functional Count & $\begin{array}{l}0.37^{b} \\
(0.14)\end{array}$ & $\begin{array}{l}0.53^{a} \\
(0.12)\end{array}$ & $\begin{array}{l}0.15^{b} \\
(0.07)\end{array}$ & $\begin{array}{l}-0.12 \\
(0.20)\end{array}$ & $\begin{array}{l}0.49^{a} \\
(0.08)\end{array}$ \\
\hline Ln Sectoral Count & $\begin{array}{c}0.20 \\
(0.13)\end{array}$ & $\begin{array}{l}0.21^{b} \\
(0.09)\end{array}$ & $\begin{array}{l}0.95^{a} \\
(0.06)\end{array}$ & $\begin{array}{l}0.45^{a} \\
(0.13)\end{array}$ & $\begin{array}{c}0.02 \\
(0.08)\end{array}$ \\
\hline Headquarters Co-location & & $\begin{array}{c}0.00 \\
(0.27)\end{array}$ & $\begin{array}{l}-0.44^{b} \\
(0.22)\end{array}$ & $\begin{array}{l}-0.64 \\
(0.45)\end{array}$ & $\begin{array}{l}-0.24 \\
(0.29)\end{array}$ \\
\hline R\&D Co-location & $\begin{array}{l}-0.37 \\
(0.39)\end{array}$ & & $\begin{array}{l}1.12^{a} \\
(0.15)\end{array}$ & $\begin{array}{c}0.48 \\
(0.36)\end{array}$ & $\begin{array}{c}0.09 \\
(0.22)\end{array}$ \\
\hline Production Co-location & $\begin{array}{l}0.56^{c} \\
(0.30)\end{array}$ & $\begin{array}{l}0.52^{a} \\
(0.16)\end{array}$ & & $\begin{array}{l}0.51^{b} \\
(0.24)\end{array}$ & $\begin{array}{l}0.34^{c} \\
(0.18)\end{array}$ \\
\hline Logistics Co-location & $\begin{array}{l}-0.56 \\
(0.48)\end{array}$ & $\begin{array}{l}-0.24 \\
(0.36)\end{array}$ & $\begin{array}{c}0.10 \\
(0.21)\end{array}$ & & $\begin{array}{l}-0.04 \\
(0.29)\end{array}$ \\
\hline $\begin{array}{l}\text { Sale \& Marketing } \\
\text { Co-location }\end{array}$ & $\begin{array}{l}-0.05 \\
(0.45)\end{array}$ & $\begin{array}{l}-0.07 \\
(0.26)\end{array}$ & $\begin{array}{l}-0.20 \\
(0.22)\end{array}$ & $\begin{array}{l}-0.35 \\
(0.40)\end{array}$ & \\
\hline $\begin{array}{l}\text { Number of observations } \\
\text { Log Likelihood }\end{array}$ & $\begin{array}{c}230 \\
-430\end{array}$ & $\begin{array}{r}390 \\
-882 \\
\end{array}$ & $\begin{array}{r}1229 \\
-2937\end{array}$ & $\begin{array}{c}217 \\
-468 \\
\end{array}$ & $\begin{array}{c}594 \\
-1374 \\
\end{array}$ \\
\hline
\end{tabular}

Note: Standard errors between parentheses: ${ }^{a},{ }^{b}$ et ${ }^{c}$ represent respectively $1 \%, 5 \%$ et $10 \%$ significance levels. Dependent variable: Location choice in the 23 countries of the enlarged European Union (EU15 and CEE8) on the five functions during the period 1997-2002. New creations of non-European firms in the manufacturing sector. 
Table 7: Location choices and functional Co-location: Mixed Logit Model

\begin{tabular}{|c|c|c|c|c|c|}
\hline \multirow[b]{2}{*}{ Variables } & \multicolumn{5}{|c|}{ Dependent Variable: Location choice } \\
\hline & Headquarters & R\&D & Production & Logistics & $\begin{array}{c}\text { Sales \& } \\
\text { Marketing }\end{array}$ \\
\hline Ln Unit Wage Cost & $\begin{array}{c}0.18 \\
(0.68)\end{array}$ & $\begin{array}{c}0.29 \\
(0.36)\end{array}$ & $\begin{array}{l}-0.62^{b} \\
(0.28)\end{array}$ & $\begin{array}{l}-0.94 \\
(0.64)\end{array}$ & $\begin{array}{c}0.25 \\
(0.21)\end{array}$ \\
\hline Heterogeneity term & & 1.16 & 1.14 & & 0.94 \\
\hline Ln Education & $\begin{array}{c}0.34 \\
(0.36)\end{array}$ & $\begin{array}{c}(0.47) \\
0.09 \\
(0.25)\end{array}$ & $\begin{array}{c}(0.27) \\
-0.30^{a} \\
(0.11)\end{array}$ & $\begin{array}{l}0.69^{a} \\
(0.27)\end{array}$ & $\begin{array}{c}(0.39) \\
0.32^{b} \\
(0.15)\end{array}$ \\
\hline Heterogeneity term & & & & & \\
\hline Ln Judicial Quality & $\begin{array}{l}1.27^{c} \\
(0.70)\end{array}$ & $\begin{array}{l}0.64^{a} \\
(0.24)\end{array}$ & $\begin{array}{l}0.39^{a} \\
(0.13)\end{array}$ & $\begin{array}{c}0.38 \\
(0.42)\end{array}$ & $\begin{array}{c}0.01 \\
(0.19)\end{array}$ \\
\hline Heterogeneity term & & & & & \\
\hline Ln GDP & $\begin{array}{l}0.50^{a} \\
(0.18)\end{array}$ & $\begin{array}{l}0.27^{a} \\
(0.09)\end{array}$ & $\begin{array}{c}0.03 \\
(0.08)\end{array}$ & $\begin{array}{l}0.58^{b} \\
(0.27)\end{array}$ & $\begin{array}{l}0.52^{a} \\
(0.08)\end{array}$ \\
\hline Heterogeneity term & & & & & \\
\hline $\begin{array}{l}\text { Ln External Market } \\
\text { Potential }\end{array}$ & $\begin{array}{l}1.28^{b} \\
(0.60)\end{array}$ & $\begin{array}{l}-0.50^{c} \\
(0.27)\end{array}$ & $\begin{array}{l}0.19^{c} \\
(0.11)\end{array}$ & $\begin{array}{l}2.26^{a} \\
(0.55)\end{array}$ & $\begin{array}{l}0.56^{a} \\
(0.19)\end{array}$ \\
\hline Heterogeneity term & $\begin{array}{c}1.81 \\
(1.10)\end{array}$ & & & $\begin{array}{c}1.57 \\
(0.90)\end{array}$ & \\
\hline Ln Functional Count & $\begin{array}{l}0.38^{b} \\
(0.18)\end{array}$ & $\begin{array}{l}0.64^{a} \\
(0.14)\end{array}$ & $\begin{array}{l}0.13^{c} \\
(0.08)\end{array}$ & $\begin{array}{l}-0.15 \\
(0.25)\end{array}$ & $\begin{array}{l}0.54^{a} \\
(0.10)\end{array}$ \\
\hline Heterogeneity term & & $\begin{array}{l}0.40 \\
(0.16)\end{array}$ & & & $\begin{array}{c}0.53 \\
(0.11)\end{array}$ \\
\hline Ln Sectoral Count & $\begin{array}{c}0.21 \\
(0.19)\end{array}$ & $\begin{array}{l}0.19^{c} \\
(0.11)\end{array}$ & $\begin{array}{l}0.96^{a} \\
(0.06)\end{array}$ & $\begin{array}{l}0.47^{a} \\
(0.14)\end{array}$ & $\begin{array}{c}0.02 \\
(0.09)\end{array}$ \\
\hline Heterogeneity term & & & & & \\
\hline Headquarters co-location & & $\begin{array}{c}0.01 \\
(0.31)\end{array}$ & $\begin{array}{c}-0.43^{b} \\
(0.21)\end{array}$ & $\begin{array}{l}-0.72 \\
(0.45)\end{array}$ & $\begin{array}{l}-0.31 \\
(0.32)\end{array}$ \\
\hline R\&D co-location & $\begin{array}{l}-0.39 \\
(0.38)\end{array}$ & & $\begin{array}{l}1.18^{a} \\
(0.15)\end{array}$ & $\begin{array}{c}0.48 \\
(0.34)\end{array}$ & $\begin{array}{c}0.14 \\
(0.23)\end{array}$ \\
\hline Production co-location & $\begin{array}{l}0.56^{c} \\
(0.29)\end{array}$ & $\begin{array}{l}0.55^{a} \\
(0.18)\end{array}$ & & $\begin{array}{c}0.52^{b} \\
(0.24)\end{array}$ & $\begin{array}{c}0.42^{b} \\
(0.18)\end{array}$ \\
\hline Logistics co-location & $\begin{array}{l}-0.59 \\
(0.52)\end{array}$ & $\begin{array}{l}-0.23 \\
(0.40)\end{array}$ & $\begin{array}{c}0.11 \\
(0.21)\end{array}$ & & $\begin{array}{l}-0.04 \\
(0.29)\end{array}$ \\
\hline $\begin{array}{l}\text { Sales \& Marketing } \\
\text { co-location }\end{array}$ & $\begin{array}{l}-0.09 \\
(0.39)\end{array}$ & $\begin{array}{l}-0.11 \\
(0.31)\end{array}$ & $\begin{array}{l}-0.22 \\
(0.21)\end{array}$ & $\begin{array}{c}-0.33 \\
0.38\end{array}$ & \\
\hline Number of observations & 230 & 390 & 1229 & 217 & 594 \\
\hline Log Likelihood & -429 & -879 & -2933 & -467 & -1368 \\
\hline
\end{tabular}

Notes: Standard errors are in parentheses with a, b, c respectively denoting significance at $1 \%, 5 \%$ and $10 \%$ levels. Mixed logit methodology with 250 simulations. Heterogeneity terms only reported if significant if significant at $10 \%$.

Dependent variable: Location choice in the 23 countries of the enlarged European Union (EU15 and CEE8) on the five functions during the period 1997-2002. New creations of non-European firms in the manufacturing sector. 
Table 8: Co-location between function in the East and West of Europe.

\begin{tabular}{||l|ccccc||}
\hline \hline \multirow{3}{*}{ Variables } & \multicolumn{5}{|c||}{ Dependent Variable: Location choice } \\
\cline { 2 - 6 } & Headquarters & R\&D & Production & Logistics & $\begin{array}{c}\text { Sales \& } \\
\text { Marketing }\end{array}$ \\
\hline \hline Headquarters Co-location & & -0.10 & $-0.66^{a}$ & -0.50 & -0.39 \\
& & $(0.27)$ & $(0.22)$ & $(0.45)$ & $(0.29)$ \\
R\&D Co-location & -0.38 & & $1.20^{a}$ & 0.55 & -0.18 \\
& $(0.38)$ & & $(0.16)$ & $(0.35)$ & $(0.23)$ \\
Production Co-location & $0.66^{b}$ & $0.58^{a}$ & & $0.66^{a}$ & $0.35^{c}$ \\
& $(0.29)$ & $(0.16)$ & & $(0.23)$ & $(0.18)$ \\
Logistics Co-location & -0.60 & -0.25 & 0.19 & & -0.05 \\
& $(0.48)$ & $(0.37)$ & $(0.21)$ & & $(0.29)$ \\
Sales \& Marketing & -0.07 & -0.15 & -0.32 & -0.16 & \\
Co-location & $(0.44)$ & $(0.26)$ & $(0.22)$ & $(0.40)$ & \\
\hline Country Fixed Effect & Yes & Yes & Yes & Yes & Yes \\
Number of observations & 230 & 390 & 1229 & 217 & 594 \\
Log Likelihood & -429 & -882 & -2937 & -468 & -1374 \\
\hline \hline
\end{tabular}

Note: Standard errors between parentheses: ${ }^{a},{ }^{b}$ et ${ }^{c}$ represent respectively $1 \%, 5 \%$ and $10 \%$ significance levels. Dependent variable: Location choice in the 23 countries of the Enlarged European Union (EU15 and CEE8) on the five functions during the period 1997-2002. New creations of non-European firms in the manufacturing sector.

1995). $R \& D$ is the only service activity which has an attractive effect on production ${ }^{40}$.

More surprisingly, the location of headquarters has a significant negative effect on the affiliates' production plant location choice. In $40 \%$ of the production co-location with headquarters, a previous $R \& D$ center is also located there, leading to awkward interactions. Removing these specific projects from the headquarters co-location variable or excluding the R\&D co-location variable eliminates the headquarters co-location effect on production ${ }^{41}$.

\footnotetext{
${ }^{40}$ Instead of considering only within-country co-location, we could have developed a more spatial analysis which would also have considered other investment realized in a "near country". These spatial complementarities between investments, also called "third country effects", have recently been studied by Bloningen et al. (2004). For the case of US outward FDI, the authors analyze the spatial autocorrelation using spatial econometrics. But contrary to our study, these authors use a quantitative dependent variable. As noted by Fleming (2004), spatial econometrics with qualitative dependent variables is only at the fundamental research stage, which prevents us using such a methodology. Even so, we have implemented the simplest alternative setup by considering, in addition to the co-location variables, the adjacent country location choice for each activity. The introduction of the five new variables leave the co-location results unchanged. The adjacent country co-location variables were always insignificant, except for R\&D location which gave importance to previous HQs location in an adjacent country with a significant coefficient at $5 \%$.

41 This could also be explained by the sequence of investments, in which firms locate headquarters only when having completely established their productive structure. So, this country will never been chosen for hosting new production plants.
} 


\section{Conclusion}

In this paper we focus on location choices of non-European multinational firms in countries of the enlarged European Union during the period 1997-2002. More specifically, we extend the literature by considering upstream and downstream service activities in addition to production activities. We present an theoretical framework and compare its predictions with the empirical results. In addition to the country characteristics, we show that the location of service activities is more affected by functional rather than by sectoral aspects. This finding corroborates theories developed by Duranton and Puga (2005), even if we consider specialisation of countries instead of cities in our present study. The demonstration of the relevance of functional specialisation at the national level may have policy implications as in our modern service economies it has become less relevant to think of specialisation in terms of sector specialization.

We also analyze the co-location of the different stages of the value chain between affiliates of multinational firms established in the enlarged European Union. We show that both $R \& D$ and production activities display co-location. Surprisingly, the location of headquarters does not appear to have any attraction effect on the location of any other part of the firm's value chain. Our work highlights some strategic aspects of location for policy makers. In fact, some functions, such as headquarters or R\&D centers, are of strategic importance for both multinational firms and host countries. But as the results demonstrate that, contrary to $R \& D$ centers, headquarters do not act as an attractor, this could call for a revision of the current policy orientation away from stimulating headquarters and towards increased subsidies to R\&D. A possible extension of our study would be to carry out a similar analysis at the regional level. With the increased importance of regional policies in the EU, this geographical scale provides an interesting and relevant next case to study the location of multinational firm investment, in particular for the headquarters or R\&D activities.

\section{References}

ANTRÀs, P. (2005), "Incomplete Contracts and the Product Cycle", American Economic Review, vol. $95 \mathrm{n}^{\mathrm{o}}$ 4: pp. 1054-1073.

Bloningen, B., Davies, R., Waddell, G. and Naughton, H. (2004), “FDI in Space : Spatial Autoregressive Relationships in Foreign Direct Investment", NBER Working Paper, vol. 10939.

BRAINARD, L. S. (1997), “ An Empirical Assessment of the Proximity-Concentration Trade-off between Multinational Sales and Trade", American Economic Review, vol. 87: pp. 520-544.

Brownstone, D. and Train, K. (1999), " Forecasting New Product Penetration with Flexible Substitution Patterns", Journal of Econometrics, vol. 89 no 1: pp. 109-129. 
Chung, W. and Song, J. (2004), "Sequential Investment, Firm Motives and Agglomeration of Japanese Electronics Firms in the US", Journal of Economics and Management, vol. $13 \mathrm{n}^{\mathrm{o}} 3$ : pp. 539-560.

DAVis, J. C. and Henderson, J. V. (2004), "The Agglomeration of Headquarters", Working Paper.

Dicken, P., Kelley, P. F., Olds, K. and YeunG, H. W.-C. (2001), “ Chains and Networks, Territories and Scales: Towards a Relational Framework for Analyzing the Global Economy", Global Networks, vol. 1 n²: pp. 99-123.

DisDier, A.-C. and MAYER, T. (2004), "How Different is eastern Europe? Structure and determinants of location choices by French firms in Eastern and Western Europe", Journal of Comparative Economics, vol. 32 n ${ }^{\circ}$ 2: pp. 280-296.

Duranton, G. and PugA, D. (2005), "From sectoral to functional urban specialisation ", Journal of Urban Economics, vol. 57 n 2: pp. 343-370.

EKHOlM, K., FORSLID, R. and MARKUSEN, J. (2003), “ Export Platform Foreign Direct Investment", NBER Working Paper, no 9517.

Feenstra, R. (2003), Advanced International Trade: Theory and Evidence, Princeton University Press.

Fleming, M. (2004), A Review of Techniques for Estimating Spatially Dependent Discrete Choice Models, Advances in Spatial Econometrics, Springer.

Gereffi, G. and Korzeniewicz, M. (1994), Commodity Chains and Global Capitalism, (eds), Westport, CT: Praeger.

Grossman, G., Helpman, E. and Szeidl, A. (2003), “Optimal Integration Strategies for the Multinational Firm", NBER Working Paper, no 10189.

Guimarães, P., Figueiredo, O. and Woodward, D. (2003), “A Tractable Approach to the Firm Location Decision Problem", Review of Economics and Statistics, vol. $85 \mathrm{n}^{\circ} 1$ : pp. 315348.

Hanson, G., Mataloni, R. and Slaughter, M. (2001), Expansion Strategies of U.S. Multinational Firms, Brookings Trade Forum 2001.

HARRIS, C. (1954), "The Market as a Factor in the Localization of Industry in the United States", Annals of the Association of American Geographers, vol. 64: pp. 315-348.

Hausman, J. and McFadden, D. (1984), "Specification Tests for the Multinomial Logit Model", Econometrica, vol. 52 no 5: pp. 1219-40.

HEAD, K. and MAYER, T. (2004), "Market Potential and the Location of Japanese Firms in the European Union", Review of Economics and Statistics, vol. 86 n 4: pp. 959-972.

HEAD, K., RIES, J. and SWEnson, D. (1995), " Agglomeration benefits and location choice : Evidence from Japanese manufacturing investment in the United-States ", Journal of International Economics, vol. 38: pp. 223-257.

Helpman, E. (1984), “ A Simple Theory of International Trade with Multinational Corporations", Journal of Political Economy, vol. 92: pp. 451-471. 
Holmes, T. J. and Stevens, J. J. (2004), "Geographic concentration and establishment size: analysis in an alternative economic geography model ", Journal of Economic Geography, vol. 4 no 3: pp. 227-250.

JONES, R. and KIERZKOWSKI, H. (1990), The Political Economy of International Trade: Festschrift in Honor of Robert Baldwin, Basil Blackwell, Oxford, chapter The Role of Services in Production and International Trade: A Theoretical Framework.

Kaufmann, D., KraAy, A. and MastruzZI, M. (2004), “Governance Matters III: Governance Indicators for 1996-2002", World Bank Working Paper, n 3106.

KEnNEY, M. and FloRIDA, R. (1994), “Japanese Maquiladoras : Production Organization and Global Commodity Chains", World Development, vol. 22 nº 1: pp. 27-44.

Krugman, P. (1995), "Growing World Trade : Causes and Consequences", Brookings Papers on Economic Activity, $\mathrm{n}^{\mathrm{o}}$ 1: pp. 327-342.

Krugman, P. and Venables, A. (1995), “Globalization and the Inequality of Nations", The Quarterly Journal of Economics, vol. 4 n ${ }^{\circ} 110$ : pp. 857-880.

Kuemmerle, W. (1997), "Building Effective R\&D Capabilities Abroad", Harvard Business Review, vol. $2 \mathrm{n}^{\mathrm{o}}$ 75: pp. 61-70.

MARKUSEN, J. R. (1984), "Multinationals, Multi-Plant Economies, and the Gains from Trade", Journal of International Economics, vol. 16: pp. 205-226.

MARKUSEN, J. R. (2002), Multinational Firms and the Theory of International Trade, Cambridge, MA and London, UK: The MIT Press.

MARKUSEN, J. R. (2005), “Modeling the Offshoring of White-Collar Services: from comparative advantage to the new theories of trade and FDI", NBER Working Paper, vol. 11827.

MAURIN, E. and Thesmar, D. (2004), "Changes in the Functional Structure of Firms and the Demand for Skill", Journal of Labor Economics, vol. $22 \mathrm{n}^{\mathrm{o}} 3$.

MCFADDEN, D. (1984), Handbook of Econometrics, Amsterdam: Elsevier/North-Holland, vol. 2, chapter Econometric Analysis of Qualitative Response Models.

NeARY, P. (2002), "Foreign Direct Investment and the Single Market", The Manchester School, vol. 70:3: pp. 291-314.

SMITH, D. and FloridA, R. (1994), "Agglomeration and Industry Location : An econometric analysis of Japanese-affiliated manufacturing establishments in automotive-related industries", Journal of Urban Economics, vol. 36: pp. 23-41.

Strauss-KaHN, V. and ViVES, X. (2005), “Why and Where do Headquarters Move ?", CEPR Working Paper, ${ }^{\circ} 5070$.

Train, K. (2003), Discrete Choice Methods with Simulation, Cambridge University Press.

UNCTAD (2002), World Investment Report: Transnational Corporations and Export Competitiveness, New York and Geneva: United Nations Conference on Trade and Development.

YEAPLE, S. (2003), " The Complex integration strategies of multinationals and cross country independencies in the structure of foreign direct investment", Journal of International Economics, vol. $60 \mathrm{n}^{\circ}$ 2: pp. 293-314.

YEUNG, W.-C. (2001), " Organizing regional production networks in Southeast Asia: implications for production fragmentation, trade and rules of origin ", Journal of Economic Geography, vol. 1: pp. 299-321. 